\title{
Mimarlık Eğitiminde Temel Tasarım Dersinde Öğrencilerin Başarıları ve Öğrenme Stilleri İlişkisi
}

\author{
Yrd. Doç. Dr. E. Elif. Özdemir
}

Makale Geliş Tarihi: 26.02.2015

Yayına Kabul Tarihi: 17.06.2016

\section{Öz}

Schön (1985), geleneksel sınıf sisteminden çeşitli yönleri ile farklılaşan mimari tasarım stüdyosu ile ilk defa karşılaşan öğrencinin geçmiş yaşamında bilmediği yeni bir dil ile tanıştığını ve eğitim sürecinin hedefinin temelde bu dilin öğretilmesine yönelik olduğunu ifade etmektedir. Tasarım stüdyosunun bu şekilde yapılanması, öğrenciye bilgi işleme süreci yoluyla düşüncelerin özgürce dışavurumunu ve paylaşımını sağlayan bir ortam yaratır. Bu düşünceden hareketle çalışma, temel tasarım stüdyosunda farklı öğrenme stillerine bireylerin çalışmaları ile başarı durumları arasındaki ilişkiyi incelemektedir. Kolb’un Öğrenme Stili Envanteri kullanılarak farklı öğrenme stilleri belirlenen mimarlık birinci sınıf öğrencilerinin, temel tasarım stüdyosu çalışmalarındaki başarı durumları arasında farklılıklar olduğu görülmüştür.

Anahtar Kelimler: Temel Tasarım Stüdyosu, Öğrenme Stilleri, Kolb Öğrenme Stili Envanteri

\section{THE RELATIONSHIP BETWEEN LEARNING STYLES AND THE ACADEMIC PERFORMANCE OF THE FIRST YEAR ARCHITECTURAL DESIGN STUDENTS}

\begin{abstract}
Schön (1985) states that the students which meets with the design studio for the first time, learns a new language which they have never known before. He told that learning in the architectural design studio makes this new language as the main aim of the architectural design education. This kind of the structure of the design studio, creates learning environment which allows to the design students express their ideas freely by the way of information processing. This paper investigates the relationship between the learning styles and the academic performance of the basic design students through architectural design education. Using Kolb's Learning Style Inventory, the results of this study indicate that there is a significant relationship between the learning styles and academic performance of the basic design students in architectural design education.
\end{abstract}

Keywords: Basic Design Studio, Learning Styles, Kolb’s Learning Styles Inventory

Yrd. Doç. Dr. E. Elif Özdemir, Mersin Üniversitesi, Mimarlık Fakültesi, Mimarlık Bölümü, Mersin.

E-posta: ozdemireelif@gmail.com 


\section{Giriş}

'Kişi senin anlattığın şekilde öğrenemiyorsa, sen onun anladığı şekilde öğret'

Çin Atasözü

İnsanı toplumsal bir varlık yapan ve onu diğer canlılardan ayıran en önemli özelliklerden biri öğrenme yeteneğine sahip olmasıdır. Doğduğu zaman bilinçli hiçbir davranış gösteremeyen insanoğlu, yaşaması için gerekli tüm davranışları çevre etkisi ve doğuştan sahip olduğu kişisel özellikleri sayesinde öğrenir. Öğrenme, değişik biçimlerde tanımlanmakla beraber psikologların birçoğu, öğrenmenin, bireyin çevresiyle etkileşim kurması sonucu gerçekleştiğini ve bireyin davranışlarında değişiklik meydana getirdiği sonucunda hemfikirdirler (Fidan, 1996).

Mimarlık eğitiminde, öğrenme etkinliği ise eylem olarak yaparak öğrenme üzerine kuruludur. Yazar (2009), mimarlık eğitiminin odağındaki tasarım stüdyolarının temelindeki yaparak öğrenme eylemini, fiziksel dışavurum yardımıyla gerçekleştirilen ve etkin bir biçimde gözlemlenebilecek davranışsal bir durum olarak tariflendiğini belirtir. Bu görüş, stüdyodaki öğrenme eyleminin, belirli fiziksel davranışların gözlenmesi ile fark edilebilir ve tasarım öğretiminin de bu somut gözlemler üzerine kurgulanabilir olduğunu destekler niteliktedir (Yazar, 2009).

Daha geniş bir perspektiften bakıldığında, yaparak ve keşfederek öğrenme biçimi, hangi bilgi türüne odaklanırsa odaklansın, tasarım etkinliğinin yapısı gereği kendiliğinden bir öğrenme durumu içerdiği fikri önem kazanmaktadır (Schön, 1984; Schön ve Wiggins, 1992). Bir başka deyişle, bu kendiliğinden öğrenme durumu, bireyin tasarım etkinliği çerçevesinde mimarlık bilgisini, kendi zihinsel çerçevesi içinde yapılandırarak edinmesi olarak tanımlanabilir.

Diğer bir taraftan tasarımda yaparak ve keşfederek öğrenme eylemi, tasarımın nasıl öğretilebileceği sorunsalına bir açıklık getirememekte ve tek başına bir öğretim yöntemini ifade edememektedir. Tasarım araştırmaları üzerine yapılan birçok çalışma, bu noktaya açıklık getirmeye çalışmaktadır. Uluoğlu (2000), tasarımın bireyler arasındaki etkileşim yoluyla öğretilebilir ve öğrenilebilir olduğu olgusundan hareketle tasarım eyleminin sadece yapmak eyleminden ibaret olmadığını, muhakeme etmeyi de içerdiği düşüncesi ile tasarımın neden hazır bilgi ve becerilerin aktarımı ile öğretilemediğini açıklamaktadır. Goldschmidt (2003) ise, 
stüdyoda kullanılan yaratıcılık ve teknik bilgi olmak üzere iki farklı bilgi türünden bahsetmektedir. Ona göre yaratıcılık öğretilemeyen ancak tarif edilebilen ve yol gösterilebilen bir bilgi türü iken teknik beceriler ise stüdyoda öğretilebilen bilgi türünü temsil etmektedir. Bu çalışma, yaparak öğrenme olgusuna, stüdyoda öğretilebilen ve öğretilemeyen iki farklı bilgi türünü bir araya getiren bir yöntem olarak bakmakta ve öğrenme eylemini bu noktada sorgulamaktadır.

Tasarım araştırmaları sonucu ortaya konan ve öğrenmenin tasarım sürecinde farklı şekilde gelişmesinden kaynaklanması ile oluşturulan bu öğrenme modellerinin temelinde, tasarım süreci boyunca öğrenmenin nasıl gerçekleştiği önem kazanmaktadır. Schön (1985), bir proje yürütücüsü ile öğrenci arasındaki iletişimden hareketle öğrencinin süreç içinde nasıl öğrendiğini, iletişim sırasında açığa çıkan sözlü ve grafik dil aracılığı ile açıklamaktadır. Bu ifade ve gramerler aracılığılla yapılan konuşmalarda, Uluoğlu (1990), mimarlık eğitimi içinde bilgi alanları arasında gidip gelen sözlü ve grafik anlatımların içiçe girerek bir bütün oluşturduğunu belirtmekte ve Schön'ün çalışmasından yola çıkarak, stüdyoda, temelde iki dilin kullanıldığını belirtmektedir. Bunlar 'tasarlamanın kendi dili' ve 'tasarlama eyleminin kendisine ait alt dil'dir (Kahvecioğlu, 2001). Mimari tasarım eğitiminde tasarım sürecinde, öğrenmenin nasıl geliştiğini anlamak için, her bireyin farklı şekilde kullandığı, tasarım bilgisinin ve bilgi setlerinin oluşturduğu düşüncenin sözlü ve grafik temsillerini aktarmaya yardımcı, 'analoji, metafor, simülasyon, tipoloji oluşturma' gibi genelde soru sorma ve önermeler üretme gibi eylemler yoluyla gelişen zihinsel faaliyetlerin bireyin tercih ettiği öğrenme şekli ile bir ilişkisi olup olmadığına ve öğrenmede hangi tür davranışların yaratıcılığı arttırmada rol oynadığına bakılabilir. Bu açıdan bu çalışma, mimarlık eğitiminde öğrenim gören birinci sınıf temel tasarım stüdyosu öğrencilerinin, öğrenme stillerini belirleyerek, onların akademik başarıları ile olan ilişkisini ortaya koymaktadır. Tasarım araştırmalarının temelini oluşturan tasarım stüdyolarında, öğrenme etkinliğinin nasıl gerçekleştiğini araştıran çalışmalara ek olarak bu çalışma, temelinde, her bireyin öğrenirken gösterdiği davranışların, bireye özgü olduğunu, farklılıklar gösterdiğini ve bu davranışların onun akademik başarısı ile olan ilişkisini araştırmaktadır.

\section{Öğrenme Stilleri}

Her birey farklı yollarla öğrenir. Bireysel farklılıklara uygun öğrenme ortamı oluşturmak, nitelikli eğitimin bir parçasıdır. Öğrenenin, aktif rol oynadığı öğrenme ortamını ifade eden, öğrenme merkezli öğretimin, temelini oluşturan bireysel özellikler üzerinde çalışmalar yapan araştırmacılar, 
eğitim- öğretimde öğrenme stillerinin önemini vurgulamışlardır.

Lewin'in Yaşantısal Öğrenme Kuramı üzerine çalışmalarını şekillendiren Kolb (1984); Jung, Piaget ve Guilford'un görüşlerini de dikkate alarak bir öğrenme stilleri modeli oluşturmuştur (Veznedaroğlu \& Özgür, 2005). Kolb öğrenme stili modelinde, öğrenme, öğrenme çemberi olarak tasarlanmıştır. Öğrenme çemberinde 4 temel öğrenme biçimi yer almıştır. Öğrencilerin etkin olabilmeleri için bu dört farklı beceriyi ortaya koymaları gerekmektedir. Bunlar, birbirini izleyen dört aşamayı oluşturmaktadır. Öğrenme stilleri de bu öğrenme biçimlerine dayalı olarak belirlenmiştir (Kolb, 1984). 1. Somut Yaşantı (CE) 2. Yansıtıcı Gözlem (RO) 3. Soyut Kavramlaştırma (AC) 4. Aktif Yaşantı (AE). Öğrenme sürecinin 4 durağan noktası vardır; 1. Somut Yaşantı 2. Gözlemler ve Yansımalar 3. Soyut Kavramların ve Genellemelerin Biçimlendirilmesi 4. Yeni durumlardaki kavramların önemini test etme (Hsu, 1999; Smith and Kolb, 1996) (Şekil 1.).

SOMUT YASANTI

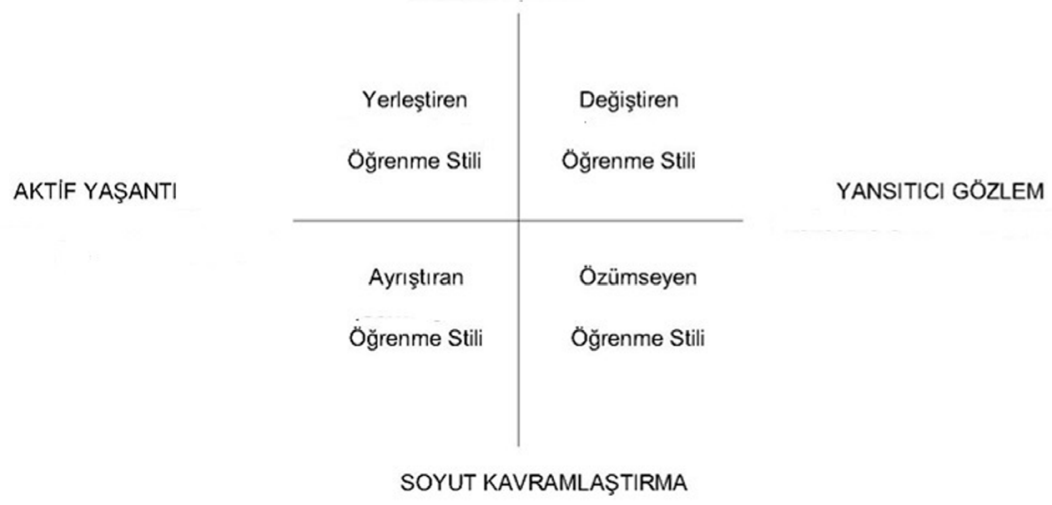

Şekil I. Kolb Öğrenme Stili Modeli (Smith \& Kolb, 1996)

\section{Öğrenme Biçimleri}

Somut Yaşantı öğrenme biçiminde, yaşantı ve problemlerle bireysel olarak ilgilenmek ve hissetmek, düşünmekten daha önemli görülmektedir. Kuram ve genellemeler yerine o anki gerçeğin tekliği ve karmaşıklığı; problemlerin çözümünde sistematik ve bilimsel bir yaklaşım yerine, sezgilere dayalı bir yaklaşım tercih edilmektedir. Bu öğrenme biçimine sahip kişiler diğer bireylerle birlikte olmaktan mutlu olurlar, gerçek olayların içinde yer almaktan zevk alırlar, yeni görüş ve düşüncelere açık, incelemeye 
hazır ve istekli olurlar, genelde sezgilere dayalı karar verme ve yapısal olmayan durumlarda başarılı olurlar. Somut yaşantı öğrenme biçiminde, bireysel yaşantılar, kişilerle etkileşim, kişi ve hislere karşı duyarlıık yoluyla gerçekleştirilen hissederek öğrenme önemlidir. Başlıca öğrenme etkinlikleri arasında yeni yaşantılar, oyunlar, rol yapma, akran grupları arasında tartışma ve bireysel çalışma yer almaktadır (Kolb,1984).

Yansıtıcı Gözlem öğrenme biçimini tercih eden bireyler ise, düşünce ve olayları dikkatlice gözlemleyerek, farklı görüş açılarından değerlendirme süreci üzerinde odaklanırlar. Bu öğrenme biçimini benimseyen kişiler, pratik uygulamalar yerine olayın özünü kavrama, doğrunun ne olduğu ve nasıl oluştuğu sorularına yanıt aramaya çalışma, düşünce ve olayları sezgi yoluyla anlama, fikirlerin oluşmasında kendi düşünce ve duygularına güvenme, sabırlı, tarafsız, dikkatli düşünerek karar verme konularında başarılıdırlar. Bu öğrenme biçiminde karar vermeden önce ilgili olay ya da olguyu dikkatlice izleme, ilgili nesneye değişik açılardan bakma, anlamını araştırma yoluyla gerçekleştirilen izleyerek ve dinleyerek öğrenme söz konusudur. Bu öğrenme biçimindeki bireyler için, gözlemci rolüyle konuyu farklı açılardan inceleme olanağı veren öğrenme-öğretme etkinlikleri, düz anlatım yönteminin ortaya konduğu ve bireyin konu ile ilgili bilgisini ölçen objektif test maddelerinden oluşan sınama durumları önerilmektedir (Kolb,1984; Kolb, Baker ve Dixon,1985).

Soyut Kavramsallaştırma öğrenme biçiminde ise mantık, kavramlar ve düşünceler, duygulardan çok daha önemli bir yere sahiptir. Genel kurallar, kuramlar geliştirme ve bir problemin çözümünde bilimsel yaklaşım önem kazanmaktadır. Bu öğrenme biçimine sahip kişiler, sistematik planlama yapma konusunda başarılıdırlar. Soyut Kavramsallaştırma öğrenme biçiminde düşünce ve olayların mantıksal analizini yaptıktan sonra harekete geçme yoluyla gerçekleştirilen düşünerek öğrenme tercih edilmektedir. Bu öğrenme biçimini benimseyen bireylerin, tek başlarına çalışarak, kuramları okuyarak öğrenmesi ve düşüncelerin yapılandırılmış bir biçimde sunulması etkin öğretim için gereklidir (Kolb,1984; Kolb, Baker ve Dixon,1985).

Aktif Yaşantı öğrenme biçiminde bireyler çevrelerini etkileme ve durumları değiştirme özelliğine sahiptir. Bu öğrenme biçiminde, izlemekten çok, pratik uygulamalar yapma, mutlak gerçek yerine işe yarayanı benimseyip, diğerlerini reddetme söz konusudur. Aktif Yaşantı öğrenme biçimine sahip bireyler başladıkları bir işi tamamlama, hedeflerine ulaşabilmek için risk alma konusunda duyarlı ve başarılı olmakta, çevreleri üzerinde etkili olmaktan ve bunun sonuçlarını görmekten mutlu olmaktadırlar. Aktif Yaşantı öğrenme biçiminde iş bitiricilik yeteneğinin ön plana çıktığı, kişi ve 
olayları davranışlarıyla etkileme yoluyla gerçekleştirilen yaparak öğrenme tercih edilmektedir. Bu öğrenme biçimini benimseyen bireyler için öğrenmeöğretme ortamları hazırlanırken daha çok uygulamaya dönük, küçük grup tartışmaları, bireysel öğrenme etkinlikleri ve projelerin yer aldığı eğitim durumlarının düzenlenmesi gerekmektedir (Kolb 1984; Kolb, Baker ve Dixon, 1985).

\section{Öğrenme Stilleri}

Modelde belirlenen öğrenme stilleri düşünme ve yaratıcılık kuramlarına dayanılarak belirlenmiş̧ir.

Soyut Kavramlaştırma ve Aktif Yaşantı biçimlerinin bileşeni ayrıştıran,

Somut Yaşantı ve Yansıtıcı Gözlem öğrenme biçimlerinin bileşeni değiştiren, Yansıtıcı Gözlem ve Soyut Kavramlaştırma biçimlerinin bileşeni özümseyen,

Somut Yaşantı ve Aktif Yaşantı biçimlerinin bileşenleri de yerleştiren öğrenme stilidir (Kolb, Baker ve Dixon, 1985).

Dört öğrenme biçimini simgeleyen öğrenme yolları birbirinden farklıdır (Aşkar ve Akkoyunlu, 1993).

Somut Yaşantı için hissederek

Yansıtıcı Gözlem için izleyerek

Soyut Kavramsallaştırma için düşünerek

Aktif Yaşantı için yaparak

öğrenir. Her birey, Kolb Öğrenme Stili Envanteri ölçeğine verdiği yanıtlardan aldığı puanlarla bu dört öğrenme stilinden birinde yer alır. Böylece daha önce Chevrier ve arkadaşlarının (2000) belirttiği gibi, insanın kendisini de nitelemeye yardımcı olacak eğilimleri ve yetenekleri de içeren bir öğrenme tipinden kolaylıkla bahsedilebilir (akt: Veznedaroğlu \& Özgür, 2005). Bu şekilde bireylerin öğrenme stilleri, öğrenme biçimleri ve bunlara bağlı öğrenme yolları Tablo 1'de verilmiştir. 


\begin{tabular}{|c|c|c|c|c|}
\hline $\begin{array}{l}\text { ÖĞRENME } \\
\text { STİLİ }\end{array}$ & \multicolumn{2}{|c|}{ ÖĞRENME BİÇİMLERİ } & \multicolumn{2}{|c|}{ ÖĞRENME YOLLARI } \\
\hline AYRIŞTIRAN & Aktif Yaşant & $\begin{array}{l}\text { Soyut } \\
\text { Kavramsallaştırma }\end{array}$ & Yaparak & Düşünerek \\
\hline ÖZÜMSEYEN & $\begin{array}{l}\text { Soyut } \\
\text { Kavramsallaştırma }\end{array}$ & Yansitıc1 Gözlem & Düşünerek & İzleyerek \\
\hline DEĞİSTIİREN & Yansitıc1 Gözlem & Somut Yaşantı & İzleyerek & Hissederek \\
\hline YERLEŞTİREN & Somut Yaşant1 & Aktif Yaşantı & His sederek & Yaparak \\
\hline
\end{tabular}

Tablo I. Kolb’un Öğrenme Stilleri, Öğrenme Biçimleri ve Bunların Öğrenme Yolları Arasındaki Ilişki (Veznedaroğlu ve Özgür, 2005)

Ayrıştıran: Soyut Kavramlaştırma ve Aktif Yaşantı'nın birleşimidir. Problem çözme, karar verme, düşüncelerin mantıksal analizi, tümdengelimci akıl yürütme ve sistematik planlama yapma bu öğrenme stiline sahip bireylerin belli başı özellikleridir. Bu bireyler sosyal ve kişilerarası etkinlikler yerine teknik sorunlarla uğraşmayı tercih etmektedirler. Yanlış problemi çözme, çabuk karar verme, odak noktasını kaçırma, düşünceleri test etmeme ve dağınık düşüncelere sahip olma en zayıf yönleridir. Ayrıştıran öğrenme stiline sahip bireylerin kendi öğrenme stillerini geliştirebilmeleri için yeni düşünme ve uygulama yolları yaratma, yeni düşüncelerini deneme, en iyi çözümü seçme, hedefler belirleme ve karar verme konularında daha çok pratik yapmaya gereksinimleri vardır. Ayrıca bu kişiler herhangi bir konuda yargılamadan anlamaya çalışma; farklı türde bilgiler arayarak bilgi kaynaklarını arttırmaya ve olayların arkasındaki gerçeklere bakarak olayların sonuçlarını zihinde canlandırma gibi yeni beceriler edinmeye gereksinim duymaktadırlar (Karakış, 2006).

Özümseyen: SoyutKavramlaştırmaveYansıtıcıGözleminkombinasyonudur. Özümseyen öğrenme stiline sahip kişiler, geniş ölçekteki bilgiyi anlamak ve onları organize ederek mantıksal ve kısa ve özlü hale getirmekte yetenekli kişilerdir. Kişilerden çok soyut fikirler ve konseptlerle ilgilidirler. Teorinin pratik değerinden çok, mantıksal sağlamlığına değer verirler. Ayrıştıran öğrenme stilinde olduğu gibi, kişiler üzerine değil fikirler ve soyut kavramlar üzerine yoğunlaşırlar; fakat özümseyen öğrenme stiline sahip bireyler, fikirlerin pratik değerleriyle ilgili daha az yargılamada bulunurlar. Onlar için önemli olan, teorinin mantıklı olmasıdır. Planlama, model yaratma, problemleri teşhis etme ve teori geliştirme, özümseyen öğrenme stiline sahip olan bireylerin başlıca güçlü yönleridir (Kolb,1984). 
Değiştiren: Somut Yaşantı ve Yansıtıcı Gözlemin birleşimidir. Bu öğrenme stiline sahip birey, somut durumlara farklı açılardan bakma konusunda çok başarılı olmaktadırlar. Olaylar karşısında harekete geçmek yerine gözlem yapmayı tercih etmekte ve beyin fırtınasında olduğu gibi farklı fikirlerin üretildiği durumlar üzerinde yoğunlaşmaktan zevk almaktadırlar. Öğrenme sürecinde sabırlı ve dikkatli olup, tarafsız yargılarda bulunabilirler. Kültürel ilgileri yoğundur, düşünceleri biçimlendirirken kendi düşünce ve duygularını göz önüne alırlar. Sanat ve hizmet verme ile ilgili mesleklerde etkin olabilmek için gerekli hayal kurma yeteneği ve hislere karşı duyarlılık özelliklerine sahiptirler. Hayal gücü, kişileri algılama, problemleri tanıma ve farklı görüş açılarını değerlendirme Değiştiren öğrenme stiline sahip bireylerin en kuvvetli yönleri; seçenekler arasında seçim yapma konusunda zorlanma, karar vermede güçlük çekme, zaman zaman problem ve fırsatları değerlendirme konusunda yetersiz kalma ise en zayıf yönleridir (Karakış, 2006).

Yerleştiren: Somut yaşantı ve aktif yaşantı öğrenme adımlarının kombinasyonudur. Yerleştiren öğrenme stiline sahip kişilerin bu yetenekleri genetiktir. Mantıksal hareket etmekten çok duygularıyla hareket etmeyi tercih ederler. Problem çözmede kendi teknik analizlerinden çok başkalarının verdikleri bilgiye güvenirler. Yerleştiren öğrenme stiline sahip bireylerin yeni fırsatlar arama, kendini hedeflere yöneltme, diğerlerini yönetme ve etkileme, diğer kişilerle etkileşim içinde bulunma ve kişisel katılım konularında daha çok pratik yaparak kendi öğrenme stillerini geliştirmeye gereksinimleri vardır. Ayrıca, yeni bilgileri toplama, özetleme, tablo haline getirme ve yeniden düzenleme; hem geçmişteki bir takım gerçeklerin açıklığa kavuşmasını hem de gelecek olaylarla ilgili tahminde bulunulmasını sağlayan kavramsal modeller oluşturma, kuram ve düşünceleri gerçekte uygulamaya geçirmeden önce test etme gibi yeni becerileri öğrenmeleri önemli görülmektedir (Karakış, 2006).

Kolb Öğrenme Stili Envanteri: Yaşantısal öğrenme teorisiüzerine temellenen öğrenme stillerini değerlendirmek için birçok araç geliştirilmiştir. En geniş kullanıma sahip olan ise Kolb Öğrenme Stili Envanteridir (Kolb's Learning Style Inventory= LSIII) (Kolb, Bakerve Dixon, 1985). Bu 1976yılındaüretilen K-LSI (I)'in geliştirilmiş halidir. K-LSI II'nin ölçeklerin iç tutarlılığını sağladığı ispatlanmıştır (Sims et.al., 1986). K-LSI (II) katılımcının kendi öğrenme çeşidini anlamaya çalışan 12 sorudan oluşan bir testtir. Katılımcılardan, sonu 4 öğrenme stili ile biten, 4 cümleyi sıralamaları istenmiştir. Her bir satırdaki derecelendirme eylemi, öğrenme sürecinin kendisine paralel olarak kavramsallaştırılmıştır ki bu katılımcıları zıt olasılıklardan birini seçmeye zorlar. 4 safhalı öğrenme modeli kutupsal zıtıkları (CE/AC vs. RO/AE) 
yansıtan yetenekleri belirler; öğrenci bu öğrenme yetenekleri arasından devamlı olarak seçmelidir. CE/AC vs. RO/AE skorları hesaplanarak, katılımcının hangi çeyrekte olduğu belirlenir (her çeyrek öğrenme stilini temsil eder) (Kolb, Baker ve Dixon, 1985; Smith \& Kolb, 1996).

Öğrenme Stillerinin mimarlık eğitimine etkisi ile ilgili birçok çalışma yapılmıştır. Bu çalışmalar ve sonuçları aşağıda sunulmuştur;

Demirbaş \& Demirkan (2003), Bilkent Üniversitesi i̇ç Mimarlık Bölümü birinci sınıf öğrencileri ile yaptığı çalışmasında, öğrencilerin öğrenme stillerinin, tasarım sürecinin dört farklı aşamasındaki başarıları üzerindeki etkisini araştırmıştır. Bu çalışmada elde edilen sonuçlar ile tasarım sürecinin farklı aşamalarında, farklı öğrenme stillerinin başarılı bir performans sergiledikleri belirlenmiştir. Kwan \& Yunyan (2005)'in araştırması da bu bulguları destekler niteliktedir. Çin'de mimarlık bölümü, ikinci ve üçüncü sınıf öğrencileri ile yaptıkları çalışmada; mimari tasarım stüdyosunda bireyin tasarım sürecinin farklı aşamalarında farklı öğrenme stillerini kullanarak başarılı olabileceğini göstermişlerdir (Özdemir, 2013). Mimarlık eğitimi ve öğrenme stillerini araştıran diğer bir çalışmada Tucker (2007), öğrenme stillerinin sabit olmadığını zaman geçtikçe değişmekte olduğunu iddia etmektedir. Diğer bir araştırmasında Tucker (2009), eğitmenleri ile aynı öğrenme stiline sahip tasarım öğrencilerinin tasarım stüdyosunda daha başarılı olduklarını ifade etmektedir. Kahire'de bir Amerikan Üniversitesinde öğrenim gören mimarlık bölümü birinci ve ikinci sınıf öğrencileri ile yaptıkları çalışmada Mostafa \& Mostafa (2010), öğrencilerin mekânsal yetenek testi ve öğrenme stilleri index'ini kullanarak belirlenen öğrenme stillerini kıyaslamıştır. Bu çalışmanın bulguları, mimarlık öğrencilerinin sözel olmaktan çok görsel, yansıtıcı öğrenenden çok aktif öğrenen ve yüksek mekânsal kalite (resim tamamlama, küplerle desen ve parça birleştirme gibi alt testleri içeren, çok boyutlu mekânda obje ya da sembolleri düzenleyebilme yeteneği) sergiledikleri yönündedir.

\section{Alan Çalışması}

Mimari tasarım eğitiminde ilk yıl, özellikle birey açısından çok önemlidir. Bu ortamda, bireyden, ortaöğrenimden elde ettiği alışkanlıklarını dönüştürmesi beklenir. Dural (2000), bu ortamı, ortaöğretimden gelen ezbere dayalı, otoriteye bağımlı, araştırmayı ve sorgulamayı bilmeyen, korkak bireyler yetiştiren eğitim sistemimizin bir sonucu olarak, 'çok boyutlu düşünme' eyleminin zorunluluk olduğu mimarlık eğitimi için büyük bir engel teşkil eden bir ortam olarak tanımlar. Dural'ın (2000), ifadesiyle ilk yıl mimarlık eğitiminin amacı, dinlerken değil, üretirken de düşünme, sorgulama ve kendini eleştirebilme becerilerinin bireye kazandırılmasıdır. 
Bu amaçla, mimarlık eğitiminin birinci yıl tasarım derslerinde çizgisel, düzlemsel ve daha sonra kütlesel elemanlarla yapılan alıştırmalar, düşüncelerini üçüncü boyuta taşıyabilme becerisinin kazandırıldığı alıştırmalar ile iki boyutlu ortamda öğrenilmiş olan düzenleme ilkeleri doğrultusunda hacimleri biraraya getirebilme yetisinin kazandırılmasını amaçlayan alıştırmalar uygulanır. Bir başka deyişle, mimarlık eğitimi ile ilk defa tanışan birey, tasarım probleminin niteliğini anlama ve kavrama, üç boyut algısı edinebilme (derinlik/ oran/ malzeme), problemi yorumlayabilme ve düşünceyi somutlaştırabilme gibi tasarlama eylemlerini gerçekleştirebilme yöntemlerini öğrenir. Tasarım problemi ile ilk defa bu süreçte karşılaşan bireylerin öğrenme farklılıklarını belirlemek amacıyla bu çalışma, 2014-2015 güz yarıyılında, Mersin Üniversitesi, Mimarlık Bölümü, birinci sınıfta eğitim gören 44 öğrenci ile yapılmıştır. Araştırmaya katılan öğrencilerden 21'i kadın, 23'ü erkektir. Öğrencilere ilk derste 12 sorudan oluşan Kolb Öğrenme stili envanteri uygulanmıştır. Daha sonra dönem boyunca yaptıkları alıştırmaların tamamı, konusunda uzman 7 öğretim üyesi tarafından tüm tasarım süreci boyunca izlenip değerlendirilmiştir. Öğretim üyeleri tarafından belirlenen akademik performanslar, çalışmaya katılan tüm öğrencilerin sahip oldukları öğrenme stilleri ile karşılaştırılmıştır.

\section{Analiz ve Değerlendirme}

Kolb öğrenme stili envanterinin değerlendirmesine göre: 15 öğrenci özümseyen, 11 öğrenci yerleştiren, 10 öğrenci değiş̧iren ve 8 öğrenci ayrıştıran öğrenme stiline sahiptir.

Öğrencilerin sahip oldukları akademik performanslar, Dereceli Puanlama Anahtarı olarak da bilinen Rubrik Değerlendirme yöntemi kullanılarak yapılmıştır. Öğrencinin gerçekleştirmesi beklenen performans tanımlarının, farklı boyut ve düzeylere bölünerek bir ölçekte gösterilmesi olarak tanımlanan (Sezer, 2015) rubrik değerlendirme yöntemi, öğrencinin performans düzeyinin saptanmasında kullanılır. Bu çalışmada kullanılan performans düzeyi kategorileri aşağıdaki tabloda gösterilmiştir (Tablo 2).

\begin{tabular}{l|c|cc|c|}
\hline $\begin{array}{l}\text { Perform ans Düzeyi } \\
\text { Kategorileri }\end{array}$ & Çok Íyi & Íyi & Orta & Zayıf \\
\hline Sayısal Tanımlar & $70-80$ & $60-69$ & $50-59$ & $49-0$ \\
\hline
\end{tabular}

Tablo 2. Çalışmada kullanılan Dereceli Puanlama Anahtarı (Sezer, 20।5)

Proje değerlendirme sürecinde performans düzeyi kategorilerini oluşturan sayısal tanımların açılımı, temel olarak iki boyutlu ve üç boyutlu çalışmalarda, bireyin verilen tasarım problemini anlaması/kavraması, üç boyut algısı 
(iki boyutlu çalışmalarda bu kriter göz önüne alınmamıştır), problemi yorumlayabilme ve tasarım problemine çözüm olarak ürettiği düşünceyi somutlaştırabilme yeteneği olarak tanımlanmıştır (Tablo 3). Mimari tasarım

\begin{tabular}{|c|c|c|c|c|}
\hline ÖLÇÜTLER & Çok Iyi & Iyi & Orta & Zayıf \\
\hline $\begin{array}{l}\text { Tasarım problemini } \\
\text { Anlama/Kavrama }\end{array}$ & $\begin{array}{l}\text { Tasarımproblemini çok } \\
\text { iyi anlax ve kavrar. }\end{array}$ & $\begin{array}{l}\text { Tasanm problemini } \\
\text { anlar ve kavrar. }\end{array}$ & $\begin{array}{l}\text { Tasanm problemini } \\
\text { anlamakta ve } \\
\text { kavramakta güçlïk } \\
\text { celer. }\end{array}$ & $\begin{array}{l}\text { Tasarim problemini } \\
\text { anlamaz ve lavrayamaz }\end{array}$ \\
\hline $\begin{array}{l}\text { Uç Boyut A1 g1s1 } \\
\text { (Derinlik, Oran, } \\
\text { Malzeme) }\end{array}$ & $\begin{array}{l}\text { Derinlik, Oran, malzeme } \\
\text { gibi etkenlerin ü̧ } \\
\text { boyutunu çok iyi alg lar. }\end{array}$ & $\begin{array}{l}\text { Derinlik, Oran, malzeme } \\
\text { gibi etkenlerin üc } \\
\text { boyu tum algilar. }\end{array}$ & $\begin{array}{l}\text { Derinlik, Oran, malzeme } \\
\text { gibi etkenlerin üf } \\
\text { boyu tum algilamakta } \\
\text { gügük çeker. }\end{array}$ & $\begin{array}{l}\text { Derinlik Oran, malzeme } \\
\text { gibi etkenlerin üc } \\
\text { boyutum al gilayamaz. }\end{array}$ \\
\hline $\begin{array}{l}\text { Problemi } \\
\text { Yormlayabilme }\end{array}$ & $\begin{array}{l}\text { Tasarım problemini çok } \\
\text { iyi yorumlar. }\end{array}$ & $\begin{array}{l}\text { Tasanm problemini } \\
\text { yorumlar. }\end{array}$ & $\begin{array}{l}\text { Tasanm problemini } \\
\text { yorumlamakta güçlük } \\
\text { çeker. }\end{array}$ & $\begin{array}{l}\text { Tasarim problemini } \\
\text { yorumlayamaz. }\end{array}$ \\
\hline $\begin{array}{l}\text { Dïşünceyi } \\
\text { Sormutlaşturabilme }\end{array}$ & $\begin{array}{l}\text { Zhinsel süreç somunda } \\
\text { elde ettiği dü ̧ెinceyi çok } \\
\text { iyi somb tlaştrabilir. }\end{array}$ & $\begin{array}{l}\text { Zhinsel süreç sominda } \\
\text { elde etti ği düşünceyi } \\
\text { somn tlaşarabilir. }\end{array}$ & $\begin{array}{l}\text { Zihins el süreç sominda } \\
\text { elde ettiği düşünceyi } \\
\text { somutlaşturmakta güghijk } \\
\text { çeker. }\end{array}$ & $\begin{array}{l}\text { Zhinsel süreç somunda } \\
\text { elde ettiği düşünceyi } \\
\text { somutlaşturamaz. }\end{array}$ \\
\hline
\end{tabular}

Tablo 3. Proje Değerlendirme Kriterleri Dereceli Puanlama Anahtarı Açılımı.

(Özdemir, 2013)

eğitimi alan 44 mimarlık birinci sınıf öğrencisi ile yapılan bu çalışmada, en çok özümseyen öğrenme stilinin tercih edildiği ( 15 kişi) ve en az ayrıştıran öğrenme stilinin tercih edildiği (8 kişi) görülmektedir (Tablo 4). Özümseyen öğrenme stilini tercih eden öğrencilerin sadece \% 26,6'sı 'çok iyi' akademik performansa sahip iken değiştiren öğrenme stilini tercih edenlerin ise \% 40'ı bu kategoridedir. Özümseyen öğrenme stilinden sonra en çok tercih edilen yerleştiren öğrenme stiline sahip bireylerin ise \%90'। 'lyi' akademik performansa sahip bulunmuştur.

\begin{tabular}{l|cc}
\hline \multicolumn{1}{c|}{ Öğrenme Stilleri } & Öğrenci Sayısı (n) & \% \\
\hline Özümseyen & 15 & 34,91 \\
Yerleştiren & 11 & 25 \\
Değiştiren & 10 & 22,72 \\
\hline Ayrıştıran & 8 & 18,18 \\
\hline TOPLAM & $\mathbf{4 4}$ & $\mathbf{1 0 0}$ \\
\hline
\end{tabular}

Tablo 4. Oğrencilerin Oğrenme Stilleri Dağılımı. 


\begin{tabular}{c|ccccc|cc|}
\hline \multicolumn{6}{c}{ Bașarı Durumu } & \multicolumn{6}{c|}{ Öğrenme Stilleri } \\
\cline { 2 - 8 } Çok Ïyi & $\mathbf{n}$ & 4 & 1 & 4 & 1 & 10 \\
& $\%$ & 40 & 10 & 40 & 10 & 100 \\
\hline \multirow{2}{*}{ İyi } & $\mathbf{n}$ & 8 & 10 & 6 & 5 & 29 \\
\cline { 2 - 8 } & $\%$ & 27,50 & 34,50 & 20,75 & 17,25 & 100 \\
\hline \multirow{2}{*}{ Orta } & $\mathbf{n}$ & 1 & - & - & 1 & 2 \\
& $\%$ & 50 & - & - & 50 & 100 \\
\hline \multirow{2}{*}{ Zayıf } & $\mathbf{n}$ & 2 & - & - & 1 & 3 \\
\cline { 2 - 8 } & $\%$ & 66,66 & - & - & 33,34 & 100 \\
\end{tabular}

Tablo 5. Öğrenme Stilleri- Akademik Performans İlişkisi.

Öğrencilerin öğrenme stilleri ve başarı durumları arasındaki ilişkiye bakıldığında özümseyen ve değiştiren öğrenme stiline sahip öğrencilerin temel tasarım dersi ödevlerinde daha başarılı oldukları görülmektedir (Tablo 5). Özümseyen öğrenme stilini tercih eden öğrencilerin \% 80 'i çok iyi ve 'iyi kategorisindeki akademik performansa sahiptirler. Özümseyen öğrenme stiline sahip bireylerin çok soyut fikirler ve konseptlerle ilgili olmalarından kaynaklandığından bu sonuç beklenmektedir (Resim 1, Resim 2). Resim 1 ve Resim 2'de görüldügü gibi özümseyen öğrenme stiline sahip bireylerin nokta çizgi çalışmasından oluşan iki boyutlu (çizgi ve nokta elemanlarını kullanarak çığlık ve koku temalarını ifade edebilmek), ve üç boyutlu çalışmalarındaki başarı, verilen tasarım problemini anlayabilme/ kavrayabilme, problemi yorumlayabilme ve ürettikleri düşüncelerini somutlaştırabilmede yetenekli oldukları görülmektedir (Resim 1, Resim 2). Özümseyen öğrenme stiline sahip bireylere yönelik sonuçların, Demirbaş ve Demirkan (2003) ve Erkan Yazıcı (2014)'nın yaptığı çalışmaların sonuçlarını desteklediği görülmektedir.
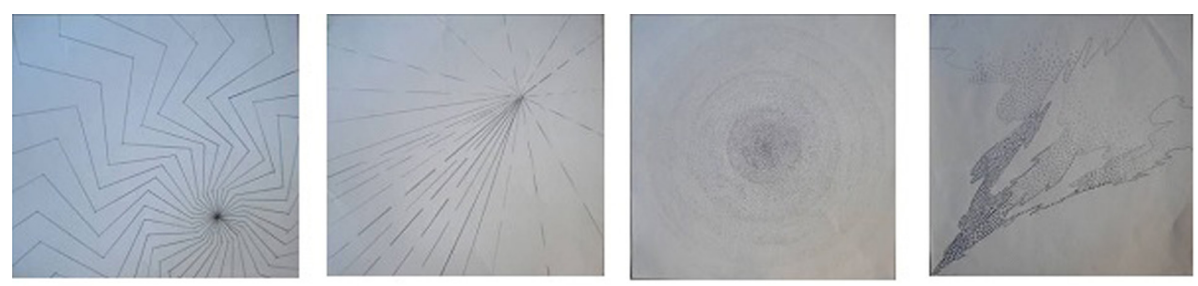

Resim I. Özümseyen Stilindeki Başarılı Öğrencilerin Iki Boyutlu Temel Tasarım Dersi Çalısmalarından Örnekler (Özdemir, 2015) 

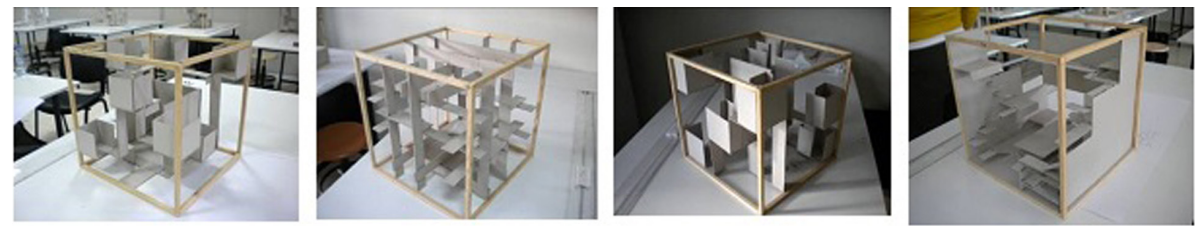

Resim 2. Özümseyen Stilindeki Başarılı Öğrencilerin Üç Boyutlu Temel Tasarım Dersi Çalısmalarından Örnekler (Özdemir, 20I5)

Diğer bir taraftan Değiştiren öğrenme stiline sahip bireylerin tamamının da başarılı olması, mimarlık eğitiminde temel tasarım dersini alan birinci sınıf öğrencileri için beklenen bir sonuç değildir. Mimarlık eğitiminin ilk yılındaki temel tasarım derslerinde öğrenciden beklenen tasarım problemini anlama ve kavrama, üç boyut algısı edinebilme, problemi yorumlayabilme ve düşünceyi somutlaştırabilme gibi yeteneklerin, somut durumlara farklı açılardan bakabilmede yetenekli olan değiştiren öğrenme stiline sahip öğrenciler için olumsuz bir etki yarattığı düşünülmektedir. Ancak bu çalışmanın bulguları, izleyerek ve hissederek öğrenmeyi tercih eden değiştiren öğrenme stiline sahip öğrencilerininde mimarlık eğitiminin ilk yılındaki temel tasarım dersinde başarılı olduklarını göstermektedir.

Öğrenme stilleri ile mimarlık eğitiminde tasarım süreci ilişkisini inceleyen çalışmaların büyük bir çoğunluğunda (Kolb, 1984; Kolb ve Kolb, 2005; Demirbaş ve Demirkan, 2003; Kwan ve Yunyan, 2005; Roberts, 2006; Tucker, 2007; Tucker, 2009; Mostafa ve Mostafa, 2010) değiştiren öğrenme stilini tercih eden bireylerin azlığı dikkat çekicidir. Bu çalışmanın, sonuçlarında elde edilen bulgulardan biri olan değiştiren öğrenme stiline sahip bireylerin fazlalığı, çalışmanın, mimarlık eğitiminin ilk yılında olan öğrencilerle yapılmasından kaynaklanmaktadır (Resim 3, Resim 4).
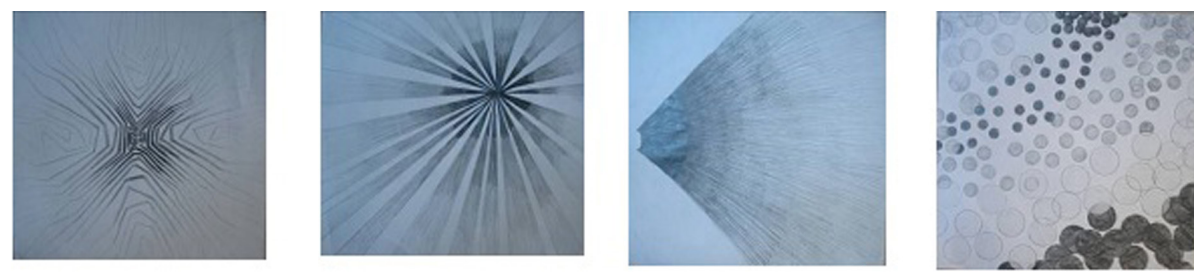

Resim 3. Değiştiren Stilindeki Başarılı Öğrencilerin Iki Boyutlu Temel Tasarım Dersi Çalışmalarından Örnekler (Özdemir, 20I5) 

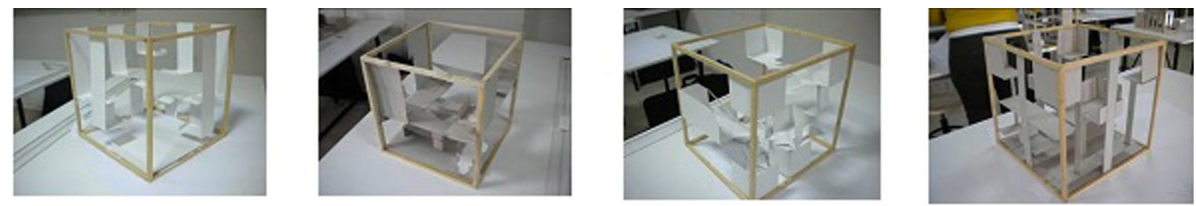

Resim 4. Değiştiren Stilindeki Başarılı Öğrencilerin Üç Boyutlu Temel Tasarım Dersi Çalısmalarından Örnekler (Özdemir, 2015)

\section{Sonuç}

Mimarlık eğitimi ile hedeflenen, öncelikli olarak bireyin kaynağını insan yaratıcılı̆̆ından alan 'tasarım' kavramı üzerine yoğunlaşan 'Mimari Tasarım Yapabilme' yeteneğinin kazandırılmasıdır. Tasarlama eylemi, farklı zihinsel aşamaları içerir. Birey, bu zihinsel aşamalarda, deneyerek, düşünerek, sezerek ve yaparak öğrenir. Birey, nasıl algıladığını, nasıl öğrendiğini bilerek, neler yapabileceğinin farkında olursa kendine göre bir tasarlama yöntemi geliştirebilir. Bu çalışma ile, farklı öğrenme süreçleri ve öğrenme stillerinin, mimarlık eğitiminde temel tasarım dersindeki akademik performansa olan etkisi araştııılmaktadır.

Bu çalışmanın bulguları, Kwan \& Yunyan (2005) ve Demirbaş \& Demirkan (2003; 2008) çalışmalarında olduğu gibi mimarlık eğitiminin tasarım stüdyolarında, öğrenme stilleri ile öğrencilerin akademik performansları arasında önemli bir ilişki oduğunu desteklemektedir. Öğrenme stilleri envanterinin mimari tasarım stüdyolarında kullanılması hem proje yürütücüsü hemde öğrenci açısından yarar sağlayacaktır. Tasarım öğrencisi açısından bakıldığında, öğrencinin öğrenme tercihini bilmesi, kendi zayıf ve güçlü yönlerinin farkına varmasına ve kendi tasarım sürecini oluşturmasına yardımcı olacaktır. Bu noktada her birey farklı yöntemler kullanarak tasarım bilgisini özümseyecek, anlamlandıracak ve yeniden yapılandıracaktır (Özdemir, 2013). Bu çalışma, bu bireysel farklılıkları araştırarak tasarım pedagojisine bir girdi olmayı amaçlamaktadır. Diğer bir taraftan her bireyin kendi yaşamsal birikimleri, kişilik özellikleri, ilgi ve isteklilik düzeyi, değerleri, yetenek örüntüsü, hayalgücü, bilgiyi işleme yöntemi, düşünürken tercih ettiği yol ve motivasyonu gibi bireyleri birbirlerinden ayıran ve bireyi farklılaştıran özgün niteliklerin tasarım sürecindeki etkisi de önemlidir (Özdemir, 2013). Tüm bu özellikler, çalışma kapsamında bireysel farklıık olarak anlamlandırımıştır.

Bu bireysel farklılık mimari tasarım stüdyosu ortamında öğrenci-proje yürütücüsü arasındaki etkileşimin daha başarılı ve verimli olması için yürütücünün, öğrencinin sahip olduğu bu kişisel öğrenme özelliklerini iyi tahlil etmesi ve ona göre bir strateji belirleyerek bireyin gelişimine katkı 
sağlaması gerekmektedir. Bu durum, aynı zamanda proje yürütücüsünün tasarım stüdyosunu yönetmesini de kolaylaştırmasına neden olacaktır. Proje yürütücüsü tarafından belirli öğrenme stillerinin, mimari tasarımda akademik performans sonuçlarının bilinmesi, stüdyo kritikleri esnasında proje yürütücüsünün öğrencinin tasarım sürecindeki eylemlerinin zayıf yönlerini güçlendirebilmesine, öğretme biçimlerinin esnekliğini arttıracak ve proje yürütücüsü ile tasarım öğrencisi arasındaki iletişimin geliştirilmesine imkân tanıyacaktır. 


\section{Kaynakça}

Aşkar, P., Akkoyunlu, B. (1993). Kolb Öğrenme Stili Envanteri. Eğitim ve Bilim Dergisi, 87: 37-47

Demirbaş, Ö.O., Demirkan, H. (2003). Focus on Architectural Design Process Through Learning Styles. Design Studies, 24 (5): 437-456.

Demirkan, H., Demirbaş, Ö.O. (2008). Focus on the Learning Styles of Freshman Design Students. Design Studies, 29 (3): 254-266.

Dural, T.A. (2000). Dönüş(tür)me Sürecinde Temel Tasarım Eğitimi. Mimarlık 293,38(3),62-66.

Erkan Yazıcı, Y. (20।4). Mimarlık Öğrencilerinin Perspektif Çizme Başarısı ile Öğrenme Stilleri Arasındaki Ilişki. Gazi Sanat ve Tasarım Dergisi, I3.sayı. Haziran. I55- 168.

Fidan, N. (1996). Okulda öğrenme ve öğretme. Ankara: Kadıŏlu Matbaası.

Goldschmidt, G. (2003, I7-19 Kasım). Expert Knowledge or Creative Spark?

Predicaments in Design Education. Design Thinking Research Symposium 6, N. Cross ve

E. Edmonds (derl.), University of Technology Sydney, Avustralya.

Hsu, C. H. C. (1999). Learning styles of hospitality students: Nature or nurture?.

Hospitality Management, 18, I7-30

Kahvecioğlu, N.P., (200I). Mimari Tasarım Eğitiminde Bilgi ve Yaratıcılık. Doktora Tezi, i.T.Ü. Fen Bilimleri Enstitüsü, İstanbul.

Karakış, Ö. (2006). Bazı Yükseköğrenim Kurumlarında Farklı Öğrenme Stillerine Sahip Olan Öğrencilerin Genel Öğrenme Stratejilerini Kullanma Düzeyleri. Yüksek Lisans Tezi. Abant Izzet Baysal Üniversitesi, Bolu.

Kolb, D. A. (1984). Experiential learning: Experience as the source of learning and development. Englewood Cliffs: NJ. Prentice Hall, p.22.

Kolb, A. Y. ve Kolb, D.A. (2005). Learning styles and learning spaces: enhancing experiential learning in higher education. Academy of Management Learning and Education. 4, 193-212

Kolb, D.A., Baker, R. ve Dixon, N. (1985). Personal learning guide: Self study booklet. Boston: MA: McBer.

Kwan T., Yunyan, J. (2005). Students' Learning Styles and Their Correlation with Performance in Architectural Design Studio. Design Studies, 26(I): 19-34 
Mostafa M, ve Mostafa H. (20I0). How do architects think? Learning Styles and Architectural Education. International Journal of Architectural Research, 4 (2-3)

Özdemir, E.E. (20/3). Mimarlık Eğitiminde Tasarım Sürecinin Geliştirilmesi Yönünde Bir Yöntem Arayışı. Doktora Tezi, Gazi Üniversitesi Fen Bilimleri Enstitüsü, Ankara.

Roberts, A. (2006). Cognitive styles and studio progression in architectural design education. Design Studies, 27(2), I67-18I

Schön, D.A. (1984). The Architectural Design Studio as an Examplar of Education for Reflection-in-action. Journal of Architectural Education, Assocaition of Collegiate Schools of Architecture, Inc. 38 (I):2-9

Schön, D. A. (1985). The design studio: an exploration of its traditions and potentials. London: RIBA Publications for RIBA Building Trust.

Schön, D.A. ve Wiggins, G. (1992). Kinds of Seeing and Their Functions in Designing. Design Studies, 13 (2): I35-156

Sims, R.R., Veres, J.G. Watson, P., and Buckner, L.E. (1986). The reliability and classification stability of the Learning Style Inventory. Educational an Psychological Management (46), Autumn, 753-760.

Smith, D.M. ve Kolb, D.A. (1996). User's Guide for the Learning Style. Baston: McBer ve Company.

Tucker, R.. (2007), Southern Drift: The Learning Styles of first and third year students of Built Environment. Architectural Science Review, 50 (3): 246-255

Tucker, R.. (2009). Getting Old and Heading South: The academic sucess of Southerner Learners in Design Cohorts. Higher Education Research and Development, 28(2): 195-207.

Uluoğlu, B. (2000). Design Knowledge Communicated in Studio Critiques. Design Studies, $2 I(I): 33-58$.

Uluoğlu, B., (1990). Mimari Tasarım Eğitimi: Tasarım Bilgisi Bağlamında Stüdyo Eleştirileri. Doktora Tezi, I.T.Ü. Fen Bilimleri Enstitüsü, İstanbul.

Willcoxson, L. ve Prosser, M. (1996). Kolb's learning style inventory (1985): Review and further study of validity and reliability. British Journal of Educational Psychology, 66, 25 I261 .

Yazar, T. (2009). Mimari Tasarım Stüdyolarında Sayısal Egzersizler. Doktora Tezi, Yıldız Teknik Üniversitesi Fen Bilimleri Enstitüsü, İstanbul. 


\section{İnternet Kaynakları}

Internet: Chevrier, J. ve diğerleri (2000). Problématique de la nature du style d'apprentissage. Le Style D'apprentissage, I7,(I).Web:http://acelf.ca/c/revue/revuehtml/28-I/0I-chevrier. html adresinden 12.06.2005'de alınmıştır.

Internet: Veznedaroğlu, R.L. ve ÖZGÜR, O.A., (2005). Öğrenme Stilleri: Tanımlamalar, Modeller ve İşlevleri. illköğretim-Online, 4(2), I-16 Web: http://ilkogretim-online.org.tr adresinden 12.06.2005'de alınmıştır.

Internet:Sezer, (2015) Web: http://pauegitimdergi.pau.edu.tr/Makaleler/1916098105_6\%C3\%96\%C4\%9ERENC\%C4\%BON\%C4\%BON\%2OAKADEM\%C4\%BOK\%20 BA\%C5\%9EARISININ\% 20BEL\%C4\%BORLENMES\%C 4\%BONDE\% 20 TAMAMLAY\%E2\%80\%A6.pdf adresinden 20.01.2015'de alınmıştır.

\section{Görsel Kaynaklar}

Şekil I. Smith, D.M. \& Kolb, D.A. (1996). User's Guide for the Learning Style. Baston: McBer ve Company

Tablo I. Veznedaroğlu, R.L. \& ÖZGÜR, O.A. (2005). Öğrenme Stilleri: Tanımlamalar, Modeller ve İşlevleri. illköğretim-Online, 4(2), I-16 Web: http://ilkogretim-online.org.tr adresinden 12.06.2005'de alınmıştır.

Tablo 2. Sezer, (2015) Web: http://pauegitimdergi.pau.edu.tr/Makaleler/1916098105 6\%C3\%96\%C4\%9ERENC\%C4\%BON\%C4\%BON\%2OAKADEM\%C4\%BOK\%20 BA\%C5\%9EARISININ\% $20 B E L \% C 4 \% B O R L E N M E S \% C 4 \% B O N D E \% 20$ TAMAMLAY\%E2\%80\%A6.pdf adresinden 20.01.2015'de alınmıştır.

Tablo 3. Özdemir, E.E. (20/3). Mimarlık Eğitiminde Tasarım Sürecinin Geliştirilmesi Yönünde Bir Yöntem Arayışı. Doktora Tezi, Gazi Üniversitesi Fen Bilimleri Enstitüsü, Ankara.

Resim I-2-3-4. Özdemir, E.E. (2015). Mersin Üniversitesi Mimarlık Fakültesi, Mimarlık Bölümü, Temel Tasarım Dersi Öğrenci Çalışmaları. 